\title{
Going by the book
}

\section{In Italy's election campaign, opposition parties have pledged research reform - but nothing will change until agency chiefs start playing by the rules.}

\begin{abstract}
f Dante were writing his Divine Comedy in today's Italy, he might still find cause to pen the line: "Laws do exist, but who is there to apply them?" But the inspiration this time would not be encounters in Purgatory with the rich and famous of medieval Italy. Instead, he might imagine meeting some of Italy's leading university professors and the presidents of its research agencies. These tortured souls would recall the many and detailed laws governing Italian academia, and their own failure to apply them.

For decades, Italy's scientists have worked under regimes that distribute money and academic positions without much fairness or transparency. Attempts to create a more equitable system have stumbled repeatedly. Just trying to survive in the system requires lots of energy that might otherwise be devoted to good science. Money has been in short supply for basic research in Italy for years, and fell after the election of Silvio Berlusconi's government in 2001. But even this cannot fully explain the feeling of stagnation in Italian research.

Rather, it is the failure to implement reforms that most depresses Italian science. For example, laws already exist that would permit researchers at the institutes of the CNR, Italy's main basic-research agency, to apply for promotion. The CNR, whose president is Fabio Pistella, is supposed to hold competitions for internal promotions every year or two. But the last one was completed seven years ago. The most recent competition was opened in 2004, yet the evaluation committee was appointed just a few weeks ago and scientists don't expect results any time soon.

There are laws allowing Italy's space agency, the ASI, to carry out space-science research, one of Italy's strengths - in fact, such research is a major part of the ASI's official mission, and the agency is relatively flush with money. Yet under the leadership of Sergio Vetrella, it has not started a new national research programme for nearly five years.

These two examples of playing safe by doing nothing are emblem-
\end{abstract}

atic of a system in which no one has to bear personal responsibility and take the consequences.

This culture has to change. Romano Prodi, leader of the centre-left coalition that is ahead in the polls in the run up to the election on 9 April, has been listening to the woes of Italy's scientists (seepage 264) and has promised to turn things around if he wins. His science advisers are aware of the problems and pledge that agency chiefs would be selected by Prodi from those competent and willing to make appropriate decisions, and that systems would be established at universities to render administrators accountable for their actions.

This could mean, for example, that when an academic appointment is made, the dean or rector involved would no longer be able to duck the blame if the professor proved to be an unproductive researcher. At the moment the buck can be passed widely, thanks to, among other things, the requirement in universities for secret faculty votes, or the
"The sort of independent evaluation that Prodi's advisers are advocating wouldattach consequences to bad decisions." fact that a candidate has been preselected by others onto the new national list of those deemed qualified to be a professor. The sort of independent evaluation that Prodi's advisers are advocating would attach consequences to bad decisions. Universities with poor research records would get less government money, and might hold their own rectors or deans accountable for the fact.

If such a system of personal responsibility sounds familiar, it is because it is already well established in most other scientifically advanced nations. But cultural change won't occur overnight in Italy. The structural adjustments that Prodi is being advised to make could nurture it, however. This would increase the chance of Dante encountering academic power-brokers not in the circles of Hell or the corridors of Purgatory, but in the meadows of Paradise.

\section{Dreams of flu data}

\section{The lack of an accessible store of information is undermining the fight against avian flu.}

/ onfidentiality of sensitive national outbreak surveillance
data assured!" This prominent guarantee on the website
of the South East Asian Nations Infectious Diseases Outbreak Surveillance Network says it all. Open sharing of data often ends when it could compromise trade or other national interests.

Massive public databases exist in many areas of science, and are critical to cutting-edge research. But there is no comprehensive database of outbreaks of infectious diseases. We have better data on galaxies 10 billion light years away than on human cases of avian flu in China or Vietnam. Yet the world is imperilled by outbreaks, wherever they happen.

It is difficult enough to gather the data in the first place. At the moment, plague, cholera and yellow fever are the only notifiable diseases that countries must report to the World Health Organization (WHO). Vietnam has often reported human cases of avian flu months after the event, and outbreaks in animals have been concealed in many countries.

Not before time, the WHO will have broader powers in 2007, when international health regulations, agreed by its members in May last year, come into force. These impose obligations on states to respond to any infectious disease of international concern. Cat-and-mouse games will no doubt continue, but the WHO will at 
least have a 'health policing' role, something that it currently lacks.

The reporting of avian-flu cases has recently improved in speed and openness, but the quality of the available data remains dire, and biological samples are insufficient. A typical WHO update will give the number of new cases from a country and, on a good day, the age, sex and rough location of each case. But there is little information on familial case clusters, and typically no clinical data. What is worse, these few data are in text form strewn across hundreds of individual WHO web pages.

Data on outbreaks in poultry are even more sparse, and mostly come from the World Organisation for Animal Health (OIE). Someone at the UN Food and Agriculture Organization (FAO) is maintaining a file of cumulative bird outbreaks from OIE and other data, and is making it available to researchers and journalists. But it is incomplete, lacks good location data and contains errors.

Genetic data are also lacking. When samples are sequenced, the results are usually either restricted by governments or kept private to an old-boy network of researchers linked to the WHO, the US Centers for Disease Control and Prevention, and the FAO. This is a far cry from the Human Genome Project, in which all the data were placed in the public domain 24 hours after sequencing. Many scientists and organizations are also hoarding sequence data, often for years, so they can be the first to publish in academic journals. With the world facing a possible pandemic, such practices are wholly unacceptable. Nature and its associated journals are not alone in supporting the rapid prior exposure of data when there are acute public-health necessities.
Three cheers, then, to Ilaria Capua of the Tri-Veneto Region Experimental Animal Health Care Institute in Italy, who last month threw down the gauntlet to her colleagues by refusing to put her latest data on Nigeria and Italy in these private networks. Instead she uploaded them to GenBank and called on her colleagues worldwide to do likewise. Only in this way can researchers establish and track the global pattern of the evolution of the bird-flu virus.

Imagine scientists anywhere being able to log on to a publidy available, searchable Internet database, updated in real time, with full clinical and sequence data on each human case, and accurate and complete poultry
"The world badly needs a database for outbreaks of avian flu." data. Dream on. The WHO's dunky online Global Health Atlas, which gives rough aggregate data for many diseases, doesn't have a category for $\mathrm{H} 5 \mathrm{~N} 1 \mathrm{under}$ influenza. The Global Infectious Diseases Epidemiology Online Network (GIDEON) database contains only the data on avian flu that it extracts from the WHO's updates and reports from the ProMED reporting system for infectious diseases. ProMED itself has pioneered outbreak alerting, notably during the SARS crisis, but its content consists largely of media cuttings. Such aggregation is often done faster and better by bloggers, and by the Global Public Health Intelligence Network (GPHIN), a Canadian intelligence operation that provides an early warning system that screens media and blogs in seven languages in real time.

The world badly needs a database for outbreaks of avian flu. But international agencies are failing to rise to the challenge.

\section{The right chemistry}

\section{Nature celebrates a discipline's unheralded achievements.}

7 elevision and cinema aren't often kind to chemists, who regularly find themselves portrayed as the nefarious creators of toxic pollutants, or as mad scientists brewing up Love Potion \#9 in some cluttered and archaic laboratory.

But most chemists innocently pass their time trying to figure out how things work at the molecular level, often using a relatively simple set of concepts to shed light on complex natural phenomena.

Fireflies, for example, communicate with each other by emitting light, and the protein responsible for this bioluminescence reaction is luciferase, which is well known to biologists. In this issue of Nature, Nakatsu and co-workers explain how they used synthetic chemistry, structural biology and biochemistry to explore how changes in the active site of the protein lead to changes in the colour of the emitted light (see pages 285 and 372).

The work is published as part of an issue in which we have collected, ahead of the American Chemical Society's meeting in Atlanta, Georgia, several chemistry and biochemistry papers along with an interview with Nobel laureate Roald Hoffmann on his work with young scientists in the Middle East (see page 274) and a NatureJobs assessment of career opportunities in green chemistry (see page 378).

In addition, Nature's website now includes a collection of recently

published Nature papers on metalloproteins, a set of proteins containing transition metals that are involved in a wide range of biologically significant processes, including DNA repair and the biosynthesis of natural products (see www.nature.com/nature/ focus/metalloproteins).

Our website also features a chemistry blog launched this week, 'The Sceptical Chymist', featuring entries by editors at Nature journals as well as by authors and readers (see http://blogs.nature.com/ thescepticalchymist). The first blog entry explains the choice of title.

Last, but not least, the website will feature a podcast including lively interviews about chemistry and biochemistry papers recently published in Nature and its sister journals. The podcast and an online collection of recent chemistry content will be

"We hope that this modest
barrage of publishing
activity will help to convey
some of the excitement
tothe wider scientific
community."
available from $23 \mathrm{March}$ (see www.nature.com/conferences/acs).

Chemists themselves probably don't need to be reminded of the usefulness of their work, or of the excitement inherent in it. We hope, however, that this modest barrage of publishing activity will help to convey some of that excitement to the wider scientific community - and even to interested observers in the world beyond. Perhaps one day even Hollywood producers will recognize the diligence with which chemists attempt to interrogate nature, and the inherent value of their contribution to our understanding of it. But don't hold your breath. 